\title{
APLIKASI TES ONLINE MENGGUNAKAN HANDPHONE DENGAN PLATFORM JAVA DAN KONEKSI GPRS
}

\author{
Andreas Handojo ${ }^{1}$, Yuliana Chandinegara, Sukanto Tedjokusumo \\ Jurusan Teknik Informatika, Fakultas Teknologi Industri, Universitas Kristen Petra \\ Jl. Siwalankerto $121-131$, Surabaya 60236 \\ E-mail : handojo@petra.ac.id ${ }^{1}$
}

\begin{abstract}
ABSTRAK: Saat ini perkembangan handphone semakin berkembang, merupakan sesuatu yang telah umum suatu handphone yang menyediakan fasilitas koneksi General Packet Radio Service (GPRS) dan fasilitas teknologi Java. Dengan adanya fasilitas Java dan GPRS ini memungkinkan adanya koneksi online menggunakan handphone ke suatu komputer server melalui internet. Hal ini mendasari pembuatan aplikasi tes online menggunakan handphone sebagai media alternatif dalam penyelenggaraan dan pengerjaan tes yang selama ini umumnya menggunakan media kertas ataupun komputer. Pada penelitian ini dikembangkan aplikasi tes online yang memungkinkan peserta handphone untuk mengerjakan tes yang terdiri dari soal multiple choice dengan single maupun multi answer, dan soal essay baik yang memiliki teks bacaan maupun tidak, serta melihat hasil tes yang pernah diikutinya. Aplikasi tes online ini menggunakan koneksi GPRS untuk berkomunikasi dengan komputer server dan dibuat dengan menggunakan bahasa pemrograman Java. Platform Java yang digunakan adalah Java 2 Micro Edition (J2ME) pada sisi handphone dan Java Server Page (JSP) pada sisi server. Berdasarkan hasil pengujian, sistem aplikasi tes online dapat berjalan dengan baik pada Nokia 6600, Nokia 7610, Nokia N73, Ben-Q Siemens EF51, dan Motorola L6 dengan menggunakan operator ProXL, IM3, Mentari, dan Simpati. Kecepatan transfer data tergantung dari kecepatan GPRS yang disediakan oleh masing-masing operator.
\end{abstract}

Kata kunci: J2ME, JSP, tes online

\begin{abstract}
Nowadays, cellular phone improves so fast and already supported by GPRS and Java technology. With this facilities enabling internet connection to computer server via cellular phone. This is the background idea to develop online test application using cellular phone to as alternative media. In this research, an online test application has been developed which enable users to take a particular test that consists of multiple choice items with either single or multi answers and essay items, whether it has reading text or not, and see their test result via their own cellular phones. This application will utilize GPRS connection to communicate with the server. This application was developed by using Java programming language. The Java platform being used is Java 2 Micro Edition (J2ME) on the cellular phone application and Java Server Page (JSP) for the server application. This application has been tested and running well on Nokia 6600, Nokia 7610, Nokia N73, Ben-Q Siemens EF51, and Motorola L6 phone using ProXL, IM3, Mentari, and Simpati communication providers. Although the communication speeds are varied among providers, the application is running as intended.
\end{abstract}

Keywords: J2ME, JSP, online test

\section{PENDAHULUAN}

Saat ini kemajuan teknologi komunikasi terutama handphone berbasis Global System for Mobile Communications (GSM) berlangsung sangat pesat. Dengan adanya banyak fitur yang ditawarkan, telah merubah handphone menjadi suatu perangkat yang multifungsi, sehingga selain sebagai alat komunikasi (fasilitas telepon, mengirim Short Message Service (SMS), dan mengirim Multimedia Messaging Service (MMS)), handphone telah berkembang menjadi sebuah komputer mini yang memungkinkan menjalankan suatu program berukuran mikro pada sebuah handphone. Ditambah adanya fitur koneksi General Packet Radio Services (GPRS) yang kini telah didukung oleh semakin banyaknya operator, maka handphone mampu untuk melakukan koneksi ke suatu komputer server melalui internet.

Hal inilah yang mendasari pembuatan aplikasi tes online menggunakan handphone sebagai media alternatif dalam penyelenggaraan dan pengerjaan tes yang selama ini umumnya menggunakan media kertas ataupun komputer. Pembuat/penyelenggara tes (examiner) dapat menyelenggarakan tes (mulai dari membuat soal, kapan tes dimulai dan diakhiri, hingga aktivasi peserta yang akan ikut) pada komputer server melalui fasilitas web, kemudian para peserta dapat melakukan koneksi GPRS ke komputer server untuk melakukan aktivasi dan mengerjakan tes. Tes online ini menggunakan koneksi GPRS untuk berkomuni- 
kasi dengan komputer server dan dibuat dengan menggunakan bahasa pemrograman Java. Platform Java yang digunakan adalah Java 2 Micro Edition (J2ME) pada sisi handphone dan Java Server Page (JSP) pada sisi server.

\section{JAVA 2 MICRO EDITION (J2ME)}

Java dikeluarkan oleh sebuah perusahaan yang bernama Sun Microsystem dalam tiga edisi yaitu: [1]

- Standard Edition (J2SE): Didesain untuk dijalankan pada personal computer.

- Enterprise Edition (J2EE): Dengan fitur built in untuk Servlet, JSP, and XML, edisi ini didesain untuk aplikasi berbasis server.

- Micro Edition (J2ME): Didesain untuk device yang memiliki keterbatasan memori, tampilan dan proses seperti handphone atau PDA (Personal Digital Assistant).

Sebagian orang telah mengenal applet sebagai aplikasi java yang berjalan pada internet yang bersifat client side atau servlet yang bersifat server side. Sedangkan untuk aplikasi pada edisi J2ME diberi nama MIDlet yang didefinisikan dari profile dan configuration untuk menjangkau bermacam-macam peserta dan device yang beragam.

J2ME merupakan kumpulan dari spesifikasi yang mendefinisikan sekumpulan platform, setiap spesifikasi akan dapat mengakomodasi kebutuhan sejumlah platform dalam scope tertentu yang sama. Setiap subset dari Java programming environment untuk beberapa perangkat tertentu didefinisikan ke dalam satu atau lebih profiles, dimana setiap profiles merupakan pengembangan kemampuan lebih lanjut dari configuration. Penentuan configuration dan profiles suatu device bergantung pada lingkungan kerja device tersebut dan tujuan pemasaran dari device tersebut.

Pada Gambar 1 dapat dilihat diagram perbandingan platform J2ME dengan platform-platform lain yang menggunakan Java sebagai programming language.

\section{Configuration}

Configuration adalah spesifikasi yang mendefinisikan software environment pada beberapa varian device yang tergantung dari: [2]

- Tipe dan jumlah memori yang tersedia

- Tipe processor dan kecepatannya

- Koneksi network yang didukung

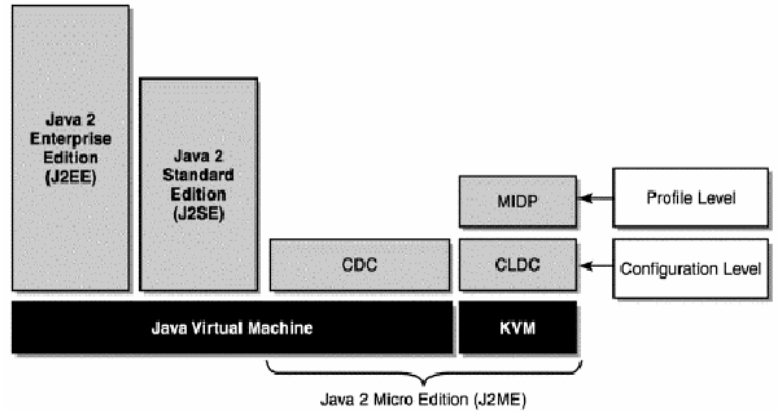

Gambar 1. Perbandingan J2ME dengan Java 2 Platform Lain [3]

Configuration digunakan sebagai platform minimal untuk suatu device tanpa adanya fitur tambahan. Pada J2ME configuration dibagi menjadi:

- Connected Limited Device Configuration (CLDC)

[2]

1. Memiliki memori 128 kilobytes untuk menjalankan java.

2. Memiliki memori 32 kilobytes untuk pengalokasian memori pada saat runtime.

3. Keterbatasan user interface.

4. Biasanya memakai tenaga baterai.

Memiliki network connectivity yang bersifat wireless, terbatas dan dengan bandwith kecil.

- Connected Device Configuration (CDC) [2]

1. Memiliki minimal 128 kilobytes untuk menjalankan java.

2. Memiliki minimal 256 kilobytes untuk pengalokasian memori pada saat runtime.

3. Memiliki network connectivity yang bersifat persistent dan dengan bandwith besar.

Sebagai contohnya, pada CLDC 1.0 tidak dikenal tipe data float sedangkan pada CLDC 1.1 mulai diperkenalkan tipe data float. Tipe data float akan sangat banyak membantu programmer untuk melakukan perhitungan dengan hasil yang lebih tepat.

\section{Profile}

Profile merupakan class tambahan yang mendukung fitur-fitur yang diperlukan pada device tertentu atau pada segmen pasar yang berbeda. Kedua configuration yang ada mempunyai satu atau lebih profile dimana kadang suatu profile digunakan untuk mendukung profile lainnya. Beberapa profile yang ada antara lain: $[1,4]$

- Mobile Information Device Profile (MIDP)

Profile ini menyediakan kemampuan untuk networking, penyimpanan data, dan component user interface. Karena MIDP didefinisikan untuk 
lingkungan yang serba terbatas maka user interface dan koneksi networking yang didukung sangatlah sederhana.

- PDA profile (PDAP)

PDA profile didefinisikan untuk PDA yang memiliki spesifikasi sedikit lebih tinggi dari pada MIDP. Application Programming Interface (API) yang disediakan digunakan pada segmen komputer kecil seperti Palm.

Meskipun MIDP versi 1.0 cukup membantu dalam membuat software yang bebas platform, namun masih kurang memuaskan bagi para pengembang software handphone. Perkembangan teknologi handphone yang begitu pesatnya memacu para pengembang software untuk membuat software yang khusus digunakan untuk suatu merk dan tipe tertentu. MIDP 1.0 awalnya ditujukan untuk mengatasi problematika ini, namun kenyataannya masih belum cukup mendukung pesertaan fitur-fitur khusus handphone.

Pada pertengahan November 2003, Sun mengeluarkan versi baru yaitu versi 2.0 yang lebih lengkap dibandingkan versi sebelumnya. Di samping masih mengandalkan beberapa fitur lama yang cukup stabil, misalnya dalam penanganan user interface dan record management dalam versi yang terbaru, beberapa fitur lama diperbarui dan diperlengkapi. Penambahan fitur yang sangat membantu dalam versi 2.0 adalah: [4]

- Multimedia: memungkinkan untuk memainkan nada sederhana dengan menggunakan perintah
playTone() yang disediakan pada package javax.microedition.media.Manager.

- Game API: sangat membantu dalam pembuatan game.

- Secure Networking: yang pada versi sebelumnya masih sangat sederhana.

\section{Record Management Store (RMS)}

RMS merupakan tempat penyimpanan data pada MIDlet (Mobile Information Device Application). Data tidak dapat langsung disimpan pada suatu file karena java tidak diberi permission untuk mengakses resource handphone secara langsung. Dengan adanya class javax.microedition.rms maka suatu data dapat disimpan secara persistent.

Record Store merupakan class yang menangani kumpulan dari record dan seluruh akses ke record haruslah melalui perantaraan class Record Store. Class ini menjamin penyimpanan data yang atomic tanpa ada kemungkinan terjadinya data corrupt.

Saat sebuah record dibuat, Record Store akan memberi nomor pada setiap record dengan nomor unique identifier yang disebut sebagai record ID. Penambahan record pertama kali akan diberi ID 1, yang kedua dengan ID 2, dan seterusnya. Record ID bukanlah suatu index, sehingga penghapusan sebuah record tidak akan mengakibatkan renumbering existing record. [4]

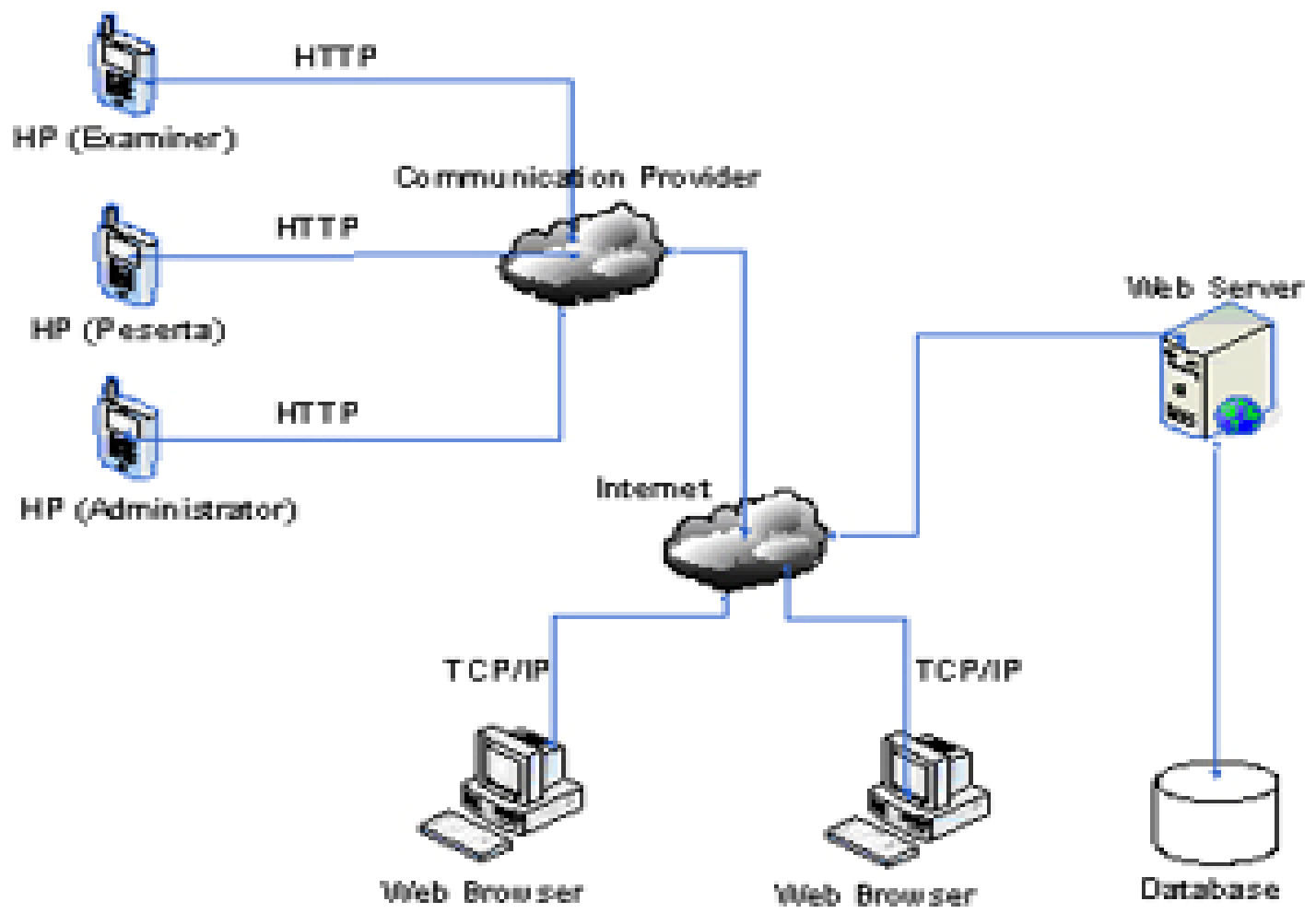

Gambar 2. Gambaran Umum Sistem Tes Online 
Tiap Record Store memiliki nama yang unik untuk membedakannya dengan Record Store yang lain. Pada MIDP 1.0, Record Store tidak dapat digunakan bersama-sama pada MIDlet yang berbeda. Sedangkan pada MIDP 2.0 sudah mendukung pesertaan Record Store yang sama pada MIDlet yang berbeda.

Jumlah penyimpanan data pada tiap handphone tidak sama dan bervariasi. Setiap MIDlet yang menggunakan RMS harus menspesifikasikan jumlah minimum dari penyimpanan yang diperlukan pada JAR (Java Archive) manifest dan application descriptor. Pengaturan nilai minimum yang berlebihan akan mengakibatkan penolakan untuk penginstall-an pada device karena space yang tersedia tidak sebanyak yang dibutuhkan.

Kecepatan akses pada persistent memori lebih lama dari kecepatan akses data yang disimpan pada variabel. Pada beberapa platform, proses writing bisa membutuhkan waktu yang lama sehingga untuk performance yang lebih bagus digunakan thread yang berbeda dari thread utama.

\section{DESAIN SISTEM}

Pengguna sistem dibagi menjadi 3 yaitu administrator, examiner (penyelenggara tes/pembuat soal/ pembuat jawaban) dan peserta tes, sedangkan media yang digunakan untuk tes online adalah media handphone dan website. Adapun gambaran umum dari sistem yang dibuat dapat dilihat pada Gambar 2, dimana aplikasi ini terbagi menjadi 3 bagian utama yaitu: aplikasi MIDlet pada handphone (administrator, examiner, peserta), aplikasi website (administrator dan examiner), dan aplikasi server yang menangani MIDlet.

Administrator dan examiner mempunyai fungsi yang berbeda dalam menjalankan website aplikasi tes online seperti yang dilihat pada Tabel 1.

Tabel 1. Fasilitas Menu Administrator dan Examiner

\begin{tabular}{lcc}
\hline \multicolumn{1}{c}{ Menu } & Administrator & Examiner \\
\hline Login & $\sqrt{ }$ & $\sqrt{ }$ \\
Home & $\sqrt{ }$ & $\sqrt{ }$ \\
Management-Subject & $\sqrt{ }$ (Add,List) & $\sqrt{ }$ (List) \\
Management-Question & & $\sqrt{ }$ (Add,List) \\
Management-Test & & $\sqrt{ }$ (Add,List) \\
Management-Answer & & $\sqrt{ }$ (List) \\
Registration-Member & $\sqrt{ }$ (Add,List) & \\
Registration-Test & $\sqrt{ }$ (Add,List) & \\
Activation-Test & $\sqrt{\text { (Add,List) }}$ & \\
Report-Transcript & $\sqrt{ }$ & $\sqrt{ }$ \\
Report-Member & $\sqrt{ }$ & $\sqrt{ }$ \\
Setting-Profile & $\sqrt{ }$ & $\sqrt{ }$ \\
Setting-Change Password & $\sqrt{ }$ & $\sqrt{ }$ \\
Logout & $\sqrt{ }$ & $\sqrt{ }$ \\
\hline
\end{tabular}

Secara garis besar proses tes online yang terdapat dalam sistem ini terdiri dari dua proses utama, yaitu : proses login, dan proses pelaksanaan tes. Adapun proses tes online dapat dilihat pada Gambar 3 .

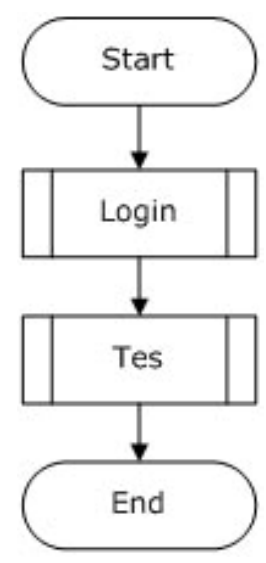

\section{Gambar 3. Flowchart Proses Tes Online}

Proses pelaksanaan tes terjadi setelah proses login berhasil dilakukan. Dalam proses pelaksanaan tes terbagi menjadi 4 (empat) proses utama seperti dapat dilihat pada Gambar 4, yaitu :

1. Proses meminta tes yang aktif

2. Proses pengerjaan tes

3. Proses pemilihan tes

4. Proses meminta hasil tes

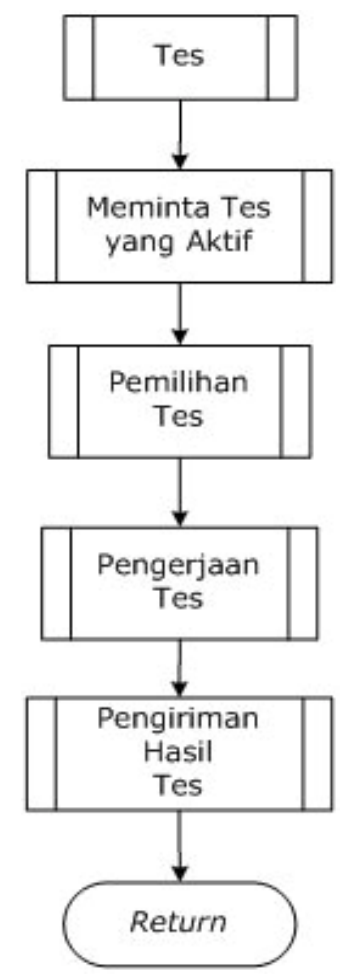

Gambar 4. Flowchart Proses Pelaksanaan Tes 
User dapat melakukan koneksi ke server untuk meminta data tes yang sedang aktif, seperti dapat dilihat pada Gambar 5.

Setelah mendapatkan daftar tes yang sedang aktif, maka user dapat memilih tes yang akan diikuti
(Gambar 6). Sistem akan mengirimkan ID user ke komputer server dan kemudian user dapat melakukan proses pengerjaan tes berdasarkan soal yang dikirimkan oleh komputer server (Gambar 7).

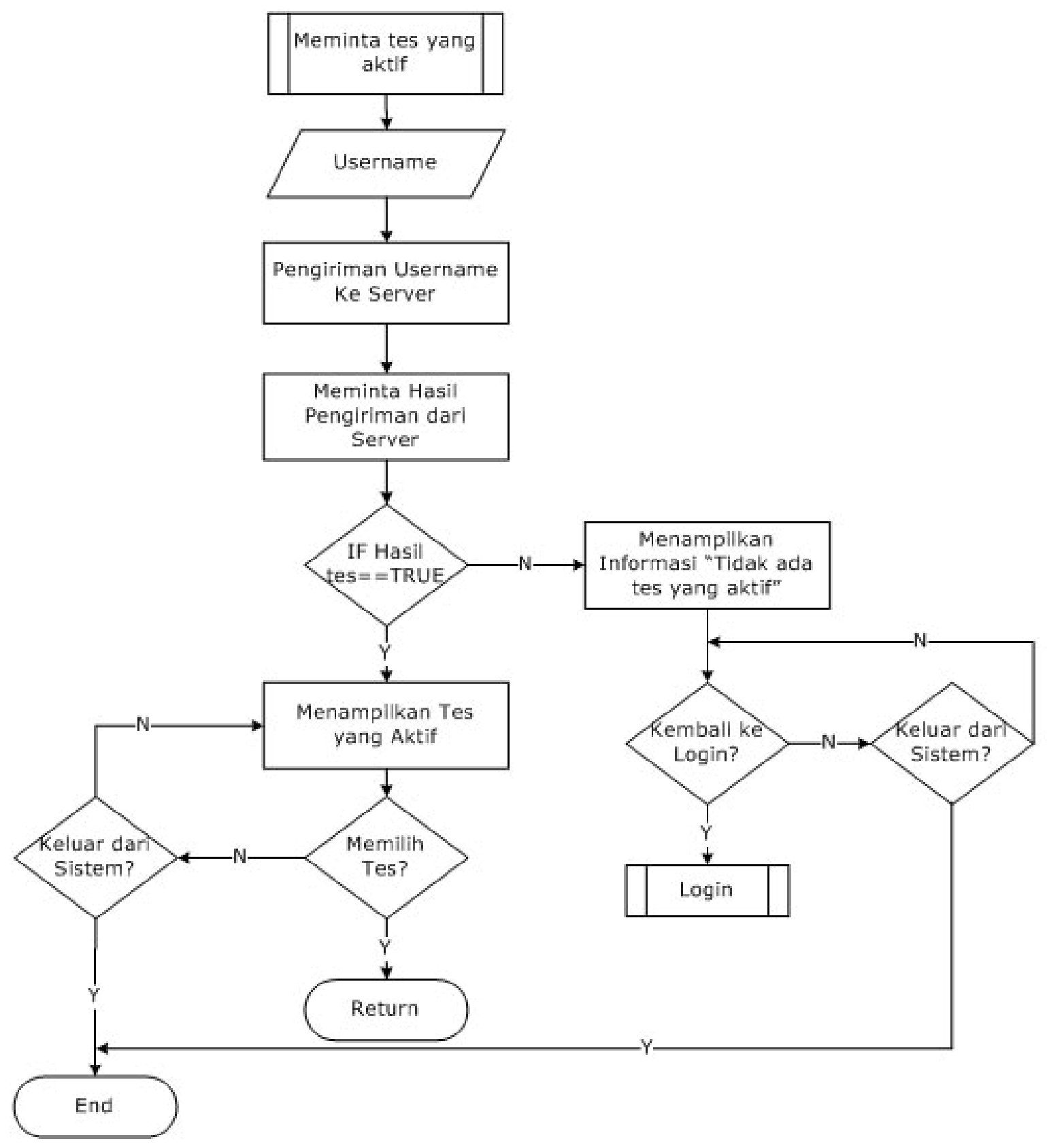

Gambar 5. Flowchart Proses Meminta Tes yang Aktif 


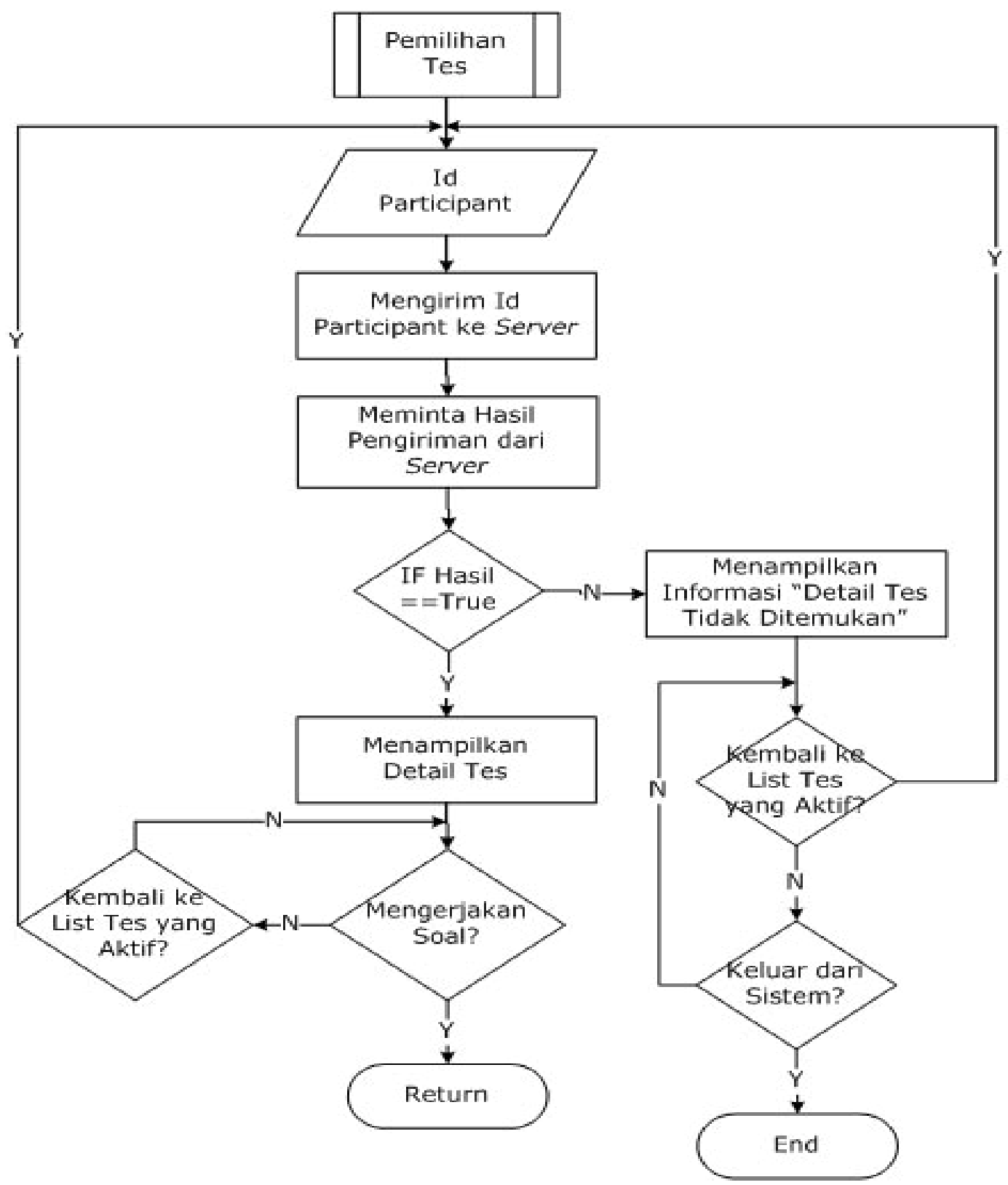

Gambar 6. Flowchart Proses Pemilihan Tes 


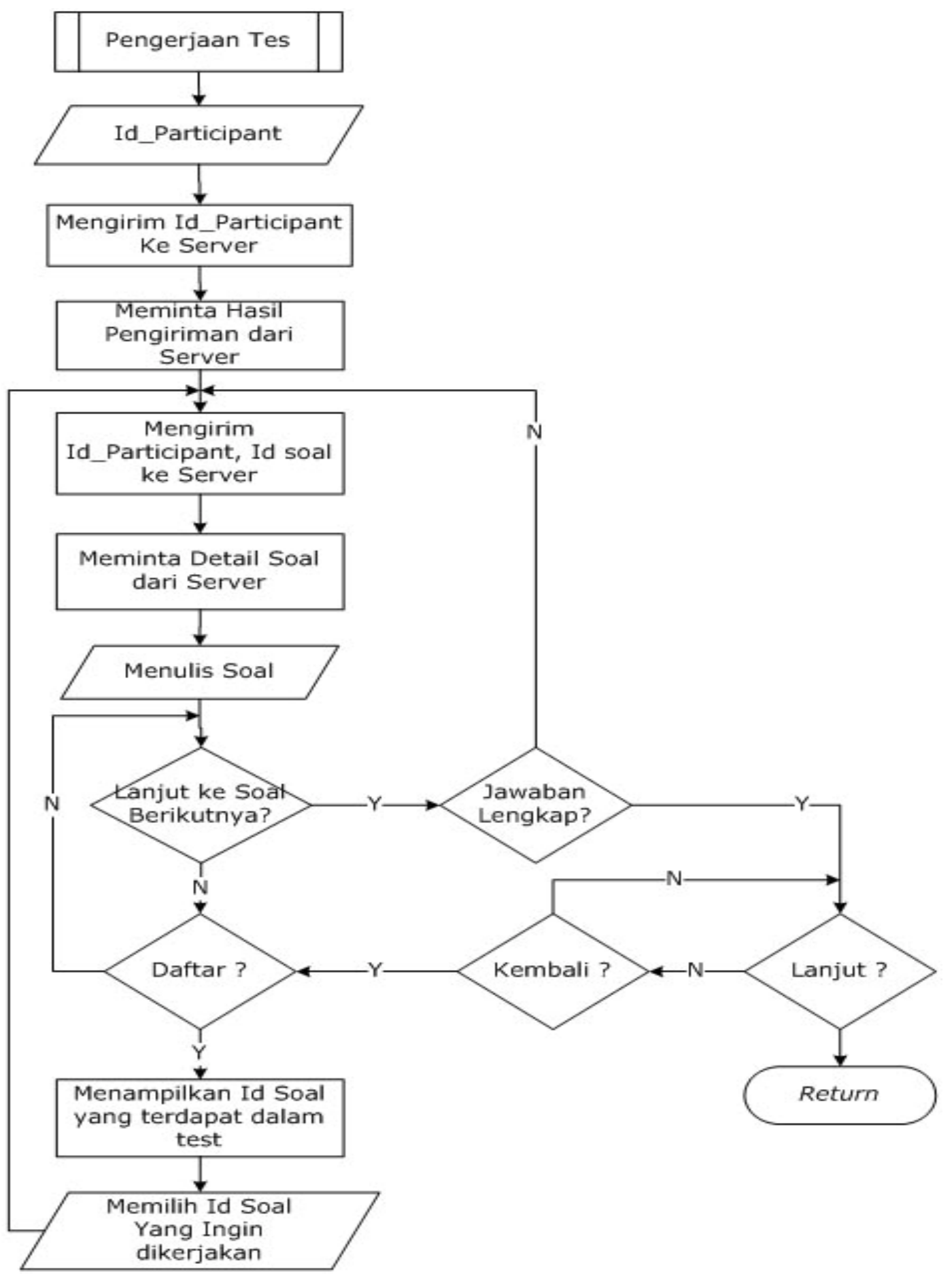

Gambar 7. Flowchart Proses Pengerjaan Tes 


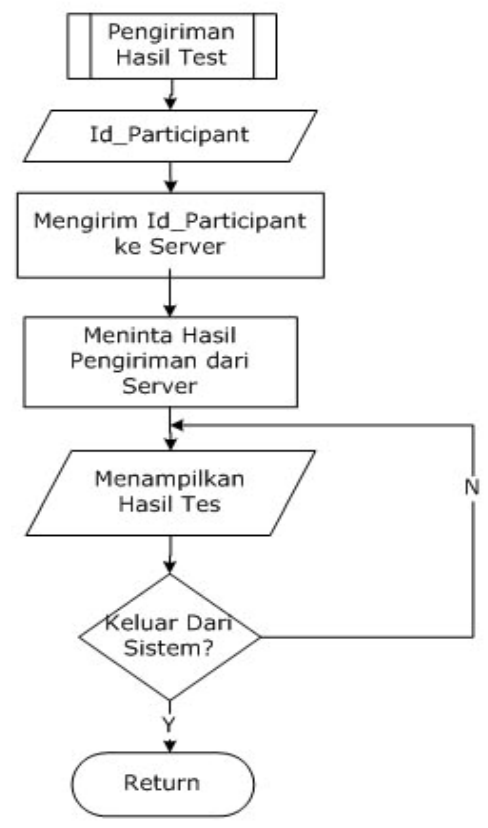

Gambar 8. Flowchart Proses Pengiriman Hasil Tes

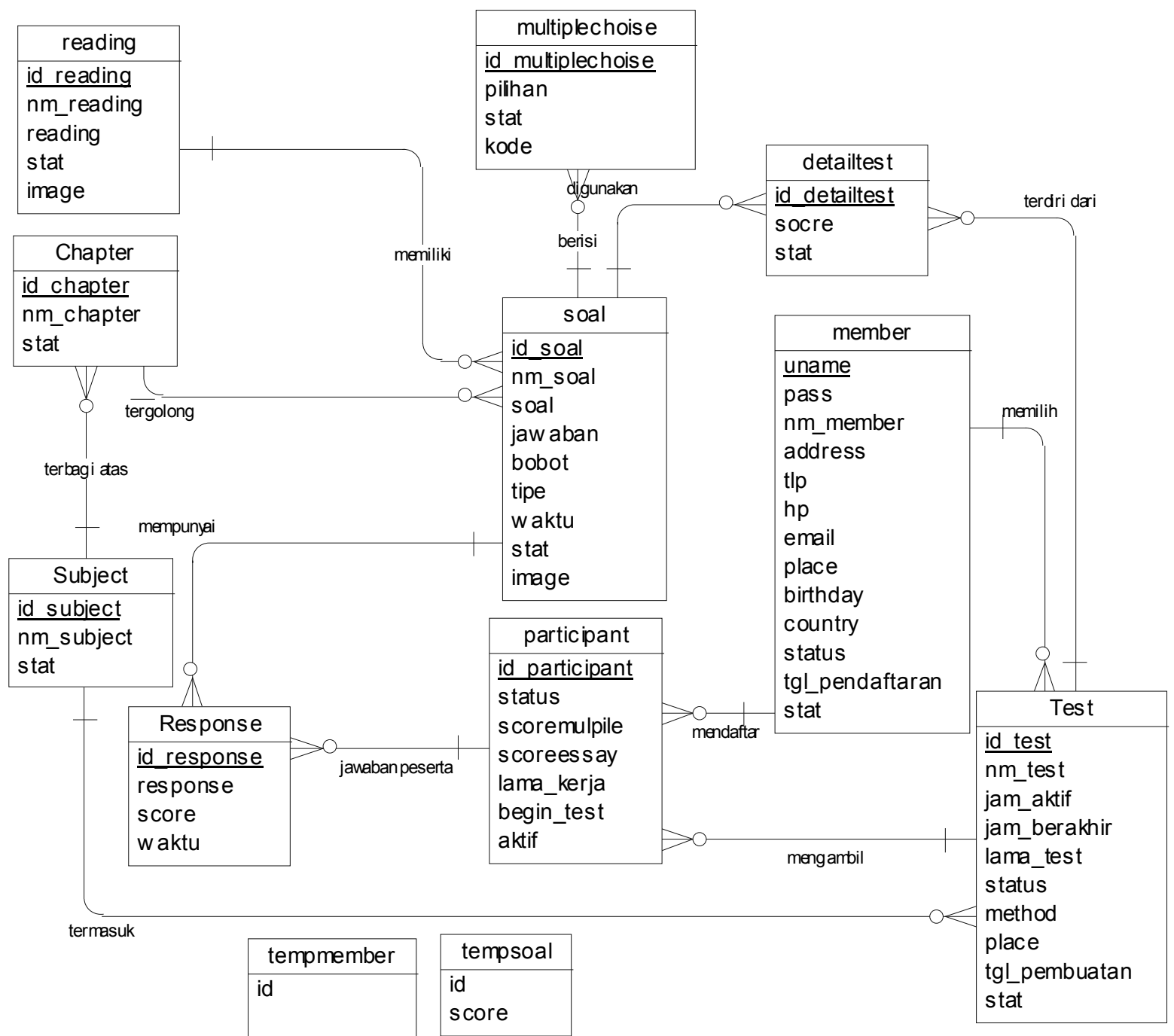


Komputer server akan melakukan proses perhitungan kemudian mengirimkan hasil tes kepada user, seperti dapat dilihat pada Gambar 8.

Guna penyimpanan data yang diperlukan digunakan database mySQL yang berfungsi selain menyimpan data soal dan tes, juga menyimpan data account member baik sebagai peserta, examiner, dan administrator, daftar nomor telepon yang teregistrasi, daftar peserta yang terdaftar dalam tes tertentu, dan juga daftar nilai peserta yang telah mengikuti tes. Data dapat diakses dan diperbaharui oleh administrator dan juga examiner melalui website berdasarkan fungsi yang dimiliki. Sedangkan desain ERD conceptual data model dapat dilihat pada Gambar 9.

\section{IMPLEMENTASI SISTEM}

Untuk implementasi dan pengujian digunakan sebuah komputer sebagai web server dengan spesifikasi sebagai berikut:

- Processor Intel Pentium IV CPU $2.0 \mathrm{GHz}$ dengan memori sebesar $512 \mathrm{MB}$

- Windows XP Professional service pack 2

- MySQL server versi 5.0

Sedangkan untuk spesifikasi handphone yang digunakan untuk pembuatan MFT MIDlet adalah sebagai berikut:

- Java-enabled MIDP device dengan CLDC versi 1.0 dan MIDP versi 2.0.

- GPRS-enabled MIDP device.

- Nokia 7610, Nokia 6600, nokia N73, Motorola L6, dan Ben-Q Siemens EF51.

Dalam membuat aplikasi administrasi, digunakan fasilitas template yang disediakan oleh Macromedia Dreamwever. Selain itu juga, digunakan Cascading Site Style (CSS) untuk memperindah halaman website. Aplikasi ini juga dibuat dengan menggunakan teknologi Asynchronous Javascript and XML (AJAX). Website ini ditulis dengan JSP karena merupakan bagian dari Java platform sehingga JSP dapat menggunakan seluruh package-package Java.

\section{Aplikasi Website}

Dalam website administrasi ini terdapat dua user, yaitu: administrator dan examiner. Masing-masing user memiliki menu yang berbeda. Untuk perbandingan menu yang tersedia pada website administrator dan website examiner dapat dilihat pada Gambar 10 dan Gambar 11.

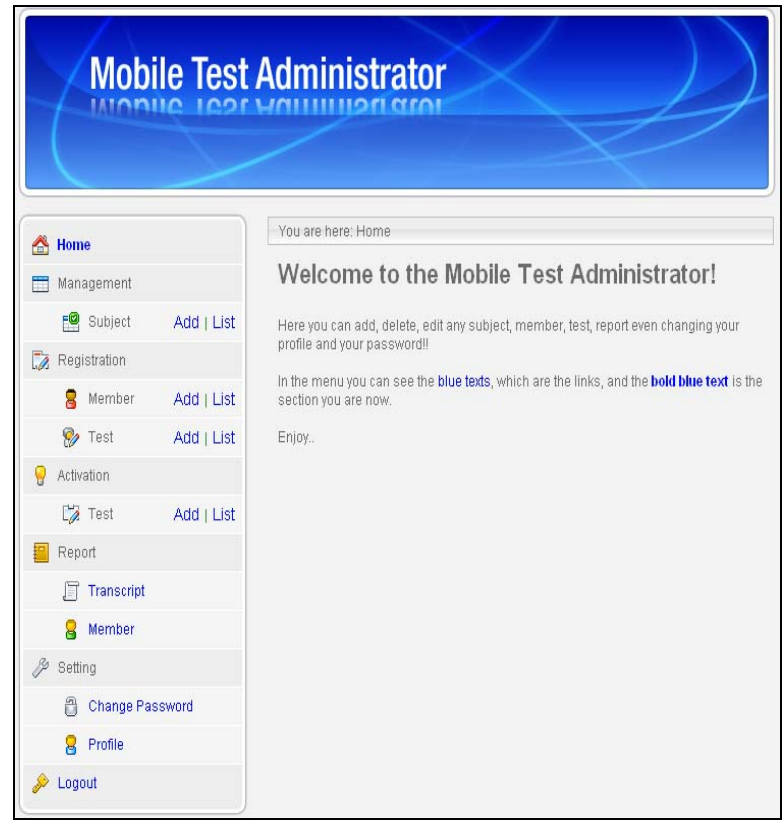

Gambar 10. Tampilan Menu Utama Administrator

Pada Gambar 10 merupakan menu yang terdapat pada website administrator, sedangkan pada Gambar 11 merupakan menu yang terdapat pada website examiner.

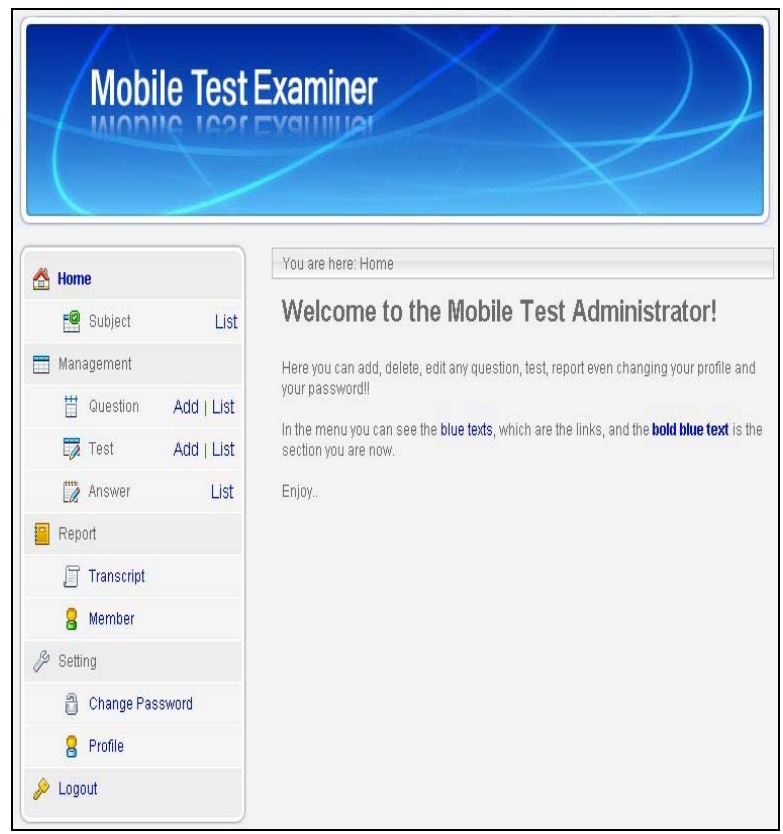

Gambar 11. Tampilan Menu Utama Examiner

Pada aplikasi ini terdapat tiga jenis soal tes yang berbeda, diantarnya soal multiple choice (single answer atau multi answer) dan soal essay. Pembuatan soal multiple choice seperti yang terlihat pada Gambar 12. 


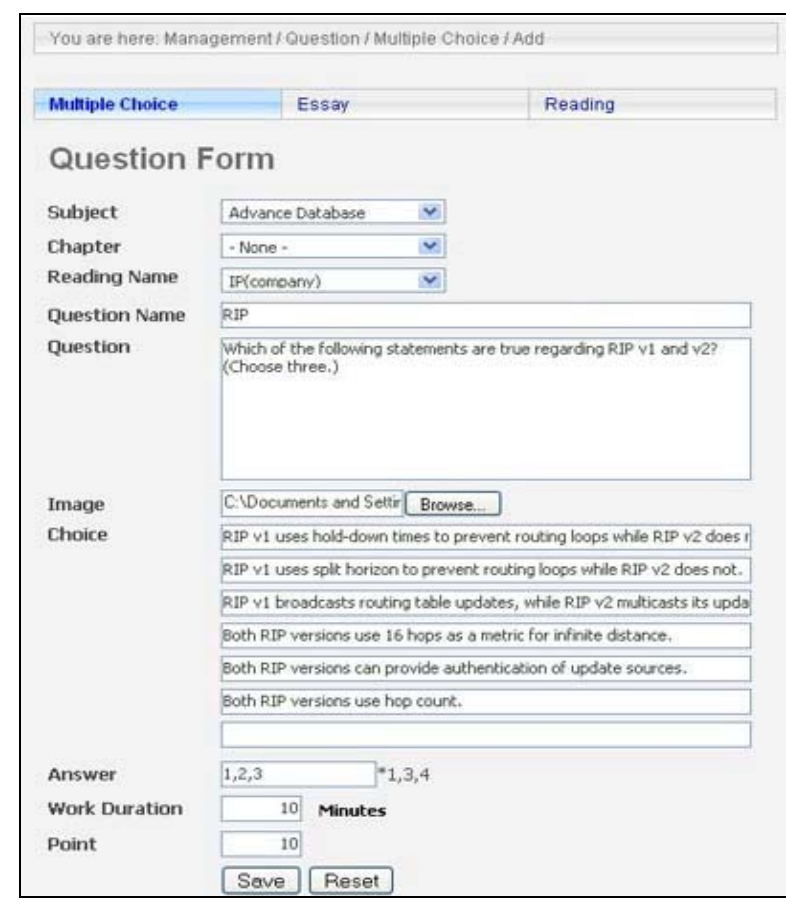

Gambar 12. Pembuatan Soal Multiple Choice Single Answer

Proses tes yang terdapat dalam sistem ini memiliki point yang berbeda untuk setiap tes dan juga dapat berbeda untuk setiap soal seperti yang terlihat pada Gambar 13. Untuk perhitungan point dan waktu dilakukan secara otomatis oleh sistem dengan menggunakan teknologi AJAX (Asynchronous Javascript and XML).

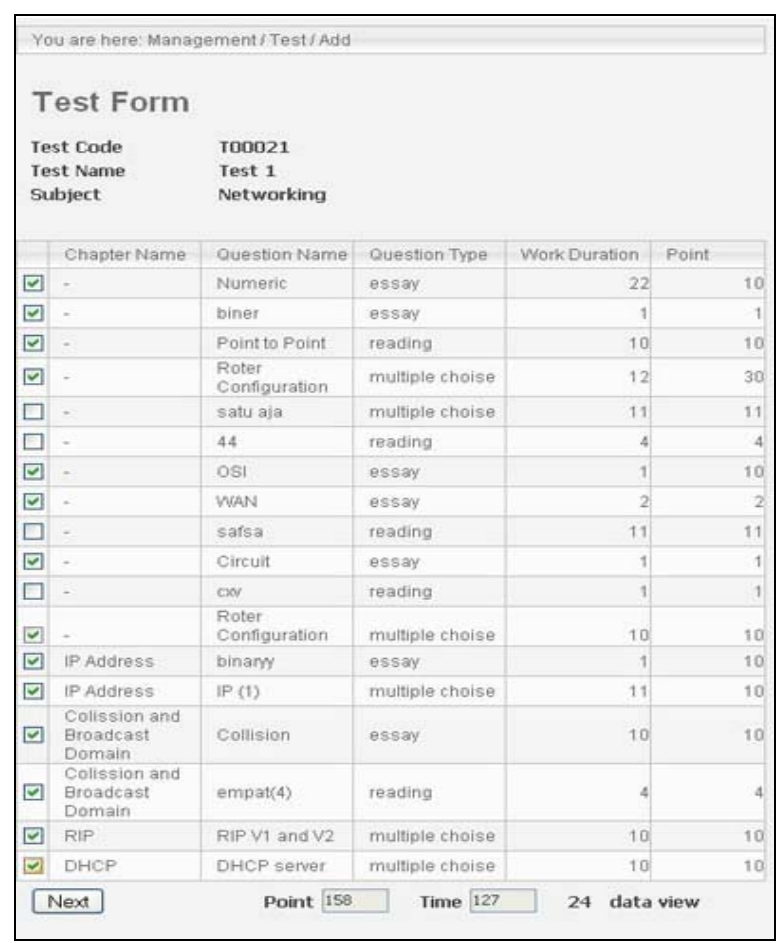

Gambar 13. Pemilihan Soal Tes

\section{Aplikasi Handphone}

Peserta dapat mengikuti tes yang telah didaftarkan dengan menginputkan username dan password sebagai authentication user. Setelah proses login berhasil maka peserta dapat melihat tes yang telah didaftarkan setelah login sukses pada halaman available test. Halaman available test dapat dilihat pada Gambar 14. Sebagai sarana uji coba, semua menu diujicobakan pada handphone TMotorola L6, Nokia 7610, Nokia N73, Ben-Q Siemens EF 51.
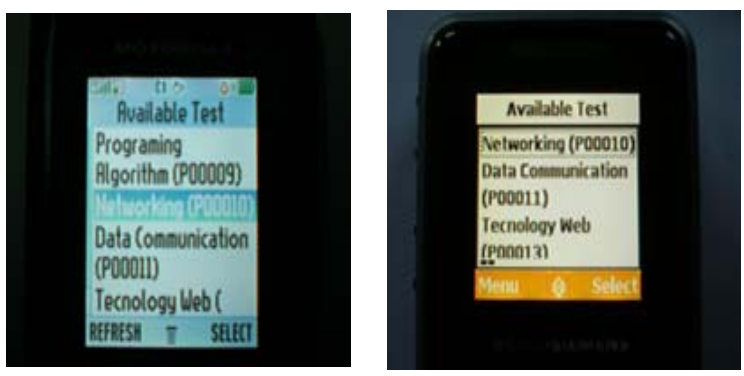

\section{Gambar 14. Halaman Available Test}

Pada halaman available test peserta dapat memilih menu select untuk mengikuti salah satu tes, menu refresh untuk meminta kembali data tes yang telah didaftarkan, dan menu history untuk melihat history test yang pernah diikuti sebelumnya seperti yang terlihat pada Gambar 15.

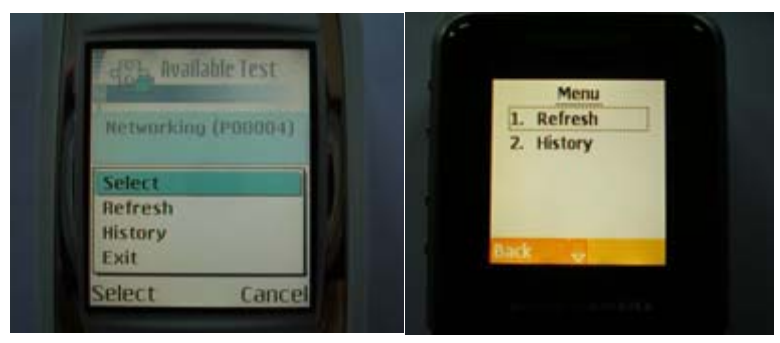

Gambar 15. T Menu Tpada T Available Test $T$

Pada halaman detail test akan menampilkan detail dari tes yang telah dipilih seperti yang terlihat pada Gambar 16.
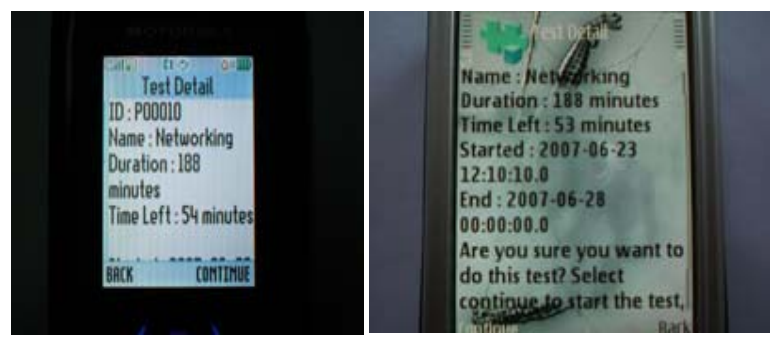

Gambar 16. Halaman TDetail Test T 
Peserta dapat mengerjakan tes setelah memilih menu continue pada halaman detail test seperti yang terlihat pada Gambar 17. Soal yang ditampilkan adalah soal yang pertama dari soal tes tertentu.
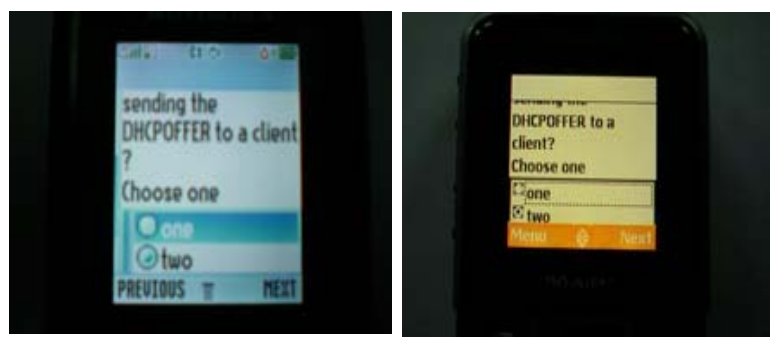

Gambar 17. TQuestion Multiple Choice Single AnswerT

Pada pelaksanan tes juga terdapat soal multiple choice multi answer yang terdapat dalam tes seperti yang terlihat pada Gambar 18.
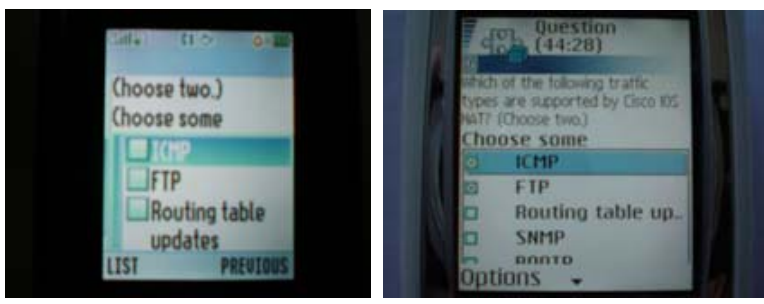

Gambar 18. TQuestion Multiple Choice Multi Answer

Selain soal multiple answer single answer dan multi answer juga terdapat soal essay seperti yang terlihat pada Gambar 19.
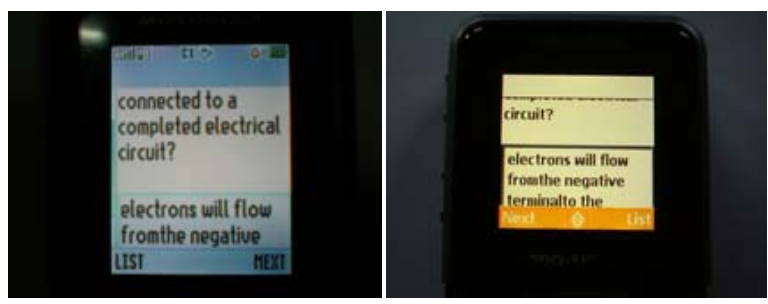

\section{Gambar 19. TQuestion Essay}

Pada halaman list question, apabila soal telah dikerjakan, maka akan ditampilkan icon seperti tanda cek di depan nama soal tertentu sehingga dapat membantu dalam pegerjaaan soal tes yang belum terselesaikan seperti yang dapat dilihat pada Gambar 20.
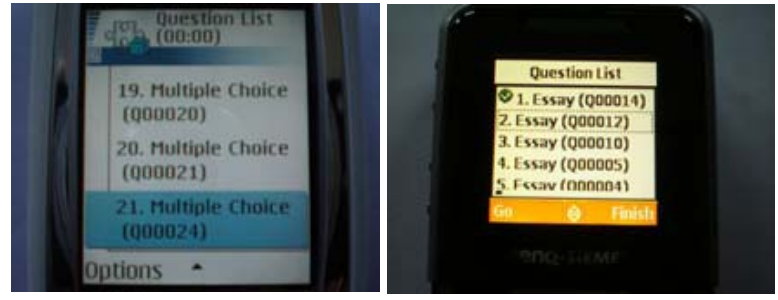

Gambar 20. Halaman TList Question

\section{KESIMPULAN}

Kesimpulan yang didapatkan dari perncangan dan pembuatan aplikasi tes online menggunakan handphone dengan platform teknologi Java dan koneksi GPRS adalah sebagai berikut :

- Aplikasi pada handphone dapat berkomunikasi dan meminta data dari server melalui perantaraan JSP. JSP tersebut kemudian berkomunikasi dengan database melalui koneksi JDBC. Selain itu, JSP juga mampu digunakan untuk menjembatani koneksi antara handphone dengan server khususnya dengan webserver.

- Posisi dari tombol-tombol perintah menu yang terdapat pada MFT MIDlet tergantung pada desain dari tombol soft keys yang ada pada setiap handphone yang digunakan.

- Kecepatan koneksi dari GPRS dari service provider sangat mempengaruhi kecepatan transfer data dari server ke client dan sebaliknya.

- Hasil tes peserta dapat disimpan di dalam handphone pada Record Management System (RMS) sehingga peserta tidak perlu melakukan koneksi ke komputer server untuk melihat kembali hasil tes yang telah dilakukan.

\section{DAFTAR PUSTAKA}

1. Leonardo, I., Pemrograman Database dengan Java. Jakarta: PT. Elex Media Komputindo, 2003.

2. Muchow, J. W., Core J2ME Technology \& MIDP, Prentice-Hall Inc, 2001.

3. Topley, K., J2ME in A Nutshell, California: O'Reilly, 2000.

4. Thamura, F., Teknik Mengembangkan Aplikasi Enterprise dengan Teknologi Open Source berbasis Java, Yogyakarta: ANDI Yogyakarta., 2005. 